\title{
Effect of Sucrose And Atonic Against Tunas Culture Potatoes (Solanum tuberosum L.) Through Tissue Culture Technique
}

\author{
Napit Suhendra Simbolon ${ }^{*}$, Revandy Iskandar Damanik ${ }^{2}$, Hot Setiado ${ }^{3}$ \\ \{napitsimbolon11@gmail.com¹, Revandy.Iskandar@usu.ac.id², hotstd@gmail.com³ \\ 1,2,3 Department of Agrotechnology, Faculty of Agriculture, University of North Sumatra \\ *napitsimbolon11@gmail.com ${ }^{1}$
}

\begin{abstract}
This study Aimed to Obtain information about the effects of sucrose and atonic cultures potato shoots. This research is complied with the basic pattern of completely randomized design (CRD) factors two items, namely sucrose $(60 \mathrm{~g} / 1,120 \mathrm{~g} / 1,180 \mathrm{~g} / \mathrm{l})$ and atonic (without tonic, $1 \mathrm{ml} / 1,1.2 \mathrm{ml} / 1,1.3 \mathrm{~m} / 1$ ), was conducted in laboratory tissue culture UPT. Horticulture Seeds Medan Johor building, room mates. Began in May 2019 and July 2019. The results Showed that sucrose administration potato shoots obtained best in culture at a concentration of $120 \mathrm{~g} / 1$, giving the best atonic potato shoots Obtained cultured at a concentration of $1 \mathrm{ml} / 1$.
\end{abstract}

Keywords: Culture shoots, potatoes, sucrose, atonic

\section{Introduction}

Potato (Solanum tuberosum L.) is a plant tubers and classified as old plants are shrubby and creeping short. It has a four square shape. Its stems and leaves are green or reddish purple colored. Its root originated from side branches that go into the ground, which serves as a store of carbohydrates so that the shape swell [1]. In 2014 the production of potatoes experienced up to $1,347,818$ tons, but in 2017 the production of potatoes has decreased approximately to $1,164,743$ tons, with an area of 75611 ha of the crop [2].

Granola cultivars currently very much cultivated by farmers. The advantages of the cultivar Granola is early duration (90 days), high yield, resistant to pests and diseases. The disadvantage is the high water content reaches $85 \%$ [3]. Today, the effort to improve the quality of potatoes in Indonesia have been conducted with several programs, one of which tissue culture methods. This method is a good way to generate production-free potato pests and diseases and can do without knowing the plant-breeding season [4].

The main factor that most determines the formation of micro-potato tuber is the type of media, sucrose concentration, type and concentration of growth regulators, as well as temperature and photoperiodic. Induction of micro-tubers can be carried out on MS medium with irradiation length of 10-16 hours [5]. This study aimed to determine the effect of sucrose and the culture of potato shoots atonic. 


\section{Research Method}

\subsection{Sterilization Equipment}

Glass tools and dissecting set (scalpel, tweezers, scissors) wash with detergent, then soaked for 24 hours $\pm 1 \times$ teepol. After submerged in the solution for 1 day, the tools are washed with running water and then in the autoclave. Then all of these tools in sterilized in an autoclave at temperatures of $121^{\circ} \mathrm{C}, 17.5$ psi for 60 minutes.

\subsection{Preparation of Solid Growing Media}

Media used in this study is Murashige and Skoog (MS), where the process of making this medium with a pipette Stock Murashige and Skoog solution into the flask, then dissolved into a solution of distilled water and added to the media. Volume media entirely determined by adding 3 liters of distilled water.

Acidity is measured by $\mathrm{pH}$ meter is 5.8 (using $1 \mathrm{~N} \mathrm{NaOH}$ and HCL $1 \mathrm{~N}$ ) to raise and lower the $\mathrm{pH}$. As a compactor is used in order to $7 \mathrm{~g} / 1$ and heated over a hot plate up so that it dissolves and homogeneous with other components, then poured into culture bottles, each bottle culture media filled $30 \mathrm{ml} /$ bottle is then closed.

\subsection{Media Sterilized}

Media in the culture bottles sterilized using an autoclave using 17.5 psi pressure autoclave at a temperature of $121^{\circ} \mathrm{C}$ for 20 minutes. Furthermore, it can be stored in the culture room with a temperature of $24^{\circ} \mathrm{C}$ before use.

\subsection{Making explants}

The explants used were books potatoes originating from potato cultivar Granola Kembang. Explant subculture is then taken and cut to a size of $0.5 \mathrm{~cm}$ using a knife over a petri dish.

\subsection{Investment Explant}

Planting explants do in LAF (Laminar Air Flow) that have been sterilized with $70 \%$ alcohol. Explant is already placed in the cup petri. The sterile bottle media and in bonding with Bunsen flame and then the explants were planted in accordance with the treatment media bottles, each bottle contained media 1 explant. After the media bottles are closed and returned to the culture room.

\subsection{Maintenance}

Bottles that have been planted with explants placed on the shelves of culture in a culture room, every day was sprayed with $70 \%$ alcohol to be free of organisms that cause contamination.

\section{Results and Discussion}

\section{1 Long Branch}

Bud long observational data on BST and finger manifold 2 in Annex 1 and 2 showed that sucrose and atonic and their interaction significantly. Shoot length between 2 BST on sucrose administration and atonic treatment can be seen in Table 1. 
Table 1. Length sprout age 2 BST on sucrose administration and atonic treatment.

\begin{tabular}{|c|c|c|c|c|c|}
\hline \multirow{2}{*}{$\begin{array}{l}\text { sucrose } \\
(G / 1)\end{array}$} & \multicolumn{4}{|c|}{ Atonic $(\mathrm{ml} / \mathrm{l})$} & \multirow[b]{2}{*}{ Mean } \\
\hline & $\mathrm{A} 0(0)$ & $\mathrm{A} 1(1)$ & A2 (2) & A3 (3) & \\
\hline S0 (60) & $20.67 \mathrm{c}$ & $21.67 \mathrm{c}$ & $\begin{array}{l}\ldots . . . \mathrm{mm} \ldots . . . \\
21: 33 \mathrm{c}\end{array}$ & $22: 00 \mathrm{bc}$ & $21: 42$ \\
\hline S1 (120) & $22: 33 \mathrm{bc}$ & $22: 00 \mathrm{bc}$ & $23.67 \mathrm{ab}$ & $23.67 \mathrm{ab}$ & 22.92 \\
\hline S2 (180) & $22: 00 \mathrm{bc}$ & $24.67 \mathrm{a}$ & $21: 33 \mathrm{c}$ & $23.67 \mathrm{ab}$ & 22.92 \\
\hline Mean & 21.67 & 22.78 & $22: 11$ & $23: 11$ & $22: 42$ \\
\hline
\end{tabular}

Description: The figure followed by the same letters in the same column indicate no significant according to Duncan's Multiple Range Test at the level of $\alpha=5 \%$.

Table 1 shows the highest shoot length at 2 BST obtained at the administration of sucrose $180 \mathrm{~g} / 1$ (S2) and atonic $1 \mathrm{ml} / 1$ (A1) that is different unreal 24.67 with S1A2, S1A3 and $\mathrm{S} 2 \mathrm{~A} 3$ and significantly different from the S0A0, S0A1, S0A2, S0A3, S1A0, S1A1, S2A0 and $\mathrm{S} 2 \mathrm{~A} 2$.

Statistical analysis of the results showed that administration of sucrose in the culture of potato shoots real effect on shoot length parameters with the best concentration of $180 \mathrm{~g} / 1$ (S2) while the parameter number of shoot and root length best results obtained at a concentration of $120 \mathrm{~g} / 1$ (S1). The less the concentration of sucrose used to a certain extent will lead to the increasing number of shoot and root length. Sucrose effects on bud formation in vitro. Giving of sucrose at lower concentrations $(20 \mathrm{~g} / \mathrm{l})$ shows the number of shoots Magnolia $\times$ soulangiana 'Coates' most [6].

\subsection{Total Tunas}

Observational data on the number of shoots BST and finger manifold 2 in Annex 3 and 4 showed that sucrose significant effect while giving atonic not significant but the interactions are both significant effect on the number of buds. The number of shoots the age of 2 BST on sucrose administration and atonic treatment can be seen in Table 2.

Table 2. Number of shoots between 2 BST on sucrose administration and atonic treatment.

\begin{tabular}{|c|c|c|c|c|c|}
\hline \multirow{2}{*}{$\frac{\text { sucrose }}{(G / 1)}$} & \multicolumn{4}{|c|}{ Atonic (ml / 1) } & \multirow[b]{2}{*}{ Mean } \\
\hline & $\mathrm{A} 0(0)$ & A1 (1) & A2 (2) & A3 (3) & \\
\hline S0 (60) & $10.67 \mathrm{~d}$ & $11.67 \mathrm{~cd}$ & $\begin{array}{l}\ldots . \text { fruit.... } \\
10: 33 \mathrm{e}\end{array}$ & $11: 33 \mathrm{~d}$ & $11: 00$ \\
\hline S1 (120) & $11.67 \mathrm{~cd}$ & ab $13: 33$ & $14: 33 \mathrm{a}$ & $13: 00 \mathrm{~b}$ & $13: 08$ \\
\hline S2 (180) & $13.67 \mathrm{ab}$ & $12.67 \mathrm{bc}$ & $11: 33 \mathrm{~d}$ & $11.67 \mathrm{~cd}$ & $12: 33$ \\
\hline Mean & $12: 00$ & $12: 56$ & $12: 00$ & $12: 00$ & $12: 14$ \\
\hline
\end{tabular}


Table 2 shows the highest number of shoots on 2 BST obtained at giving sucrose $120 \mathrm{~g} /$ 1 (S1) and atonic $2 \mathrm{ml} / 1$ (A2) that is different unreal 14.33 with S1A1 and S2A0 and significantly different from the S0A0, S0A1, S0A2, S0A3, S1A0, S1A3, S2A1, S2A2 and $\mathrm{S} 2 \mathrm{~A} 3$.

Statistical analysis of the results showed that administration of sucrose in the culture of potato shoots real effect on shoot length parameters with the best concentration of $180 \mathrm{~g} / 1$ (S2) while the parameter number of shoot and root length best results obtained at a concentration of $120 \mathrm{~g} / 1$ (S1). The less the concentration of sucrose used to a certain extent will lead to the increasing number of shoot and root length. Sucrose effects on bud formation in vitro. Giving of sucrose at lower concentrations $(20 \mathrm{~g} / 1)$ shows the number of shoots Magnolia $\times$ soulangiana 'Coates' most [6].

Giving atonic in cultures of potato shoots influential not evident on the parameters of the number of shoots, initial weight and final weight where the highest data on each - each of these parameters tend to be obtained on administration atonic with a concentration of $1 \mathrm{ml} / 1$ (A1), $3 \mathrm{ml} / 1$ (A3) and $2 \mathrm{ml} / 1$ (A2). Atonic is a growth regulator that serves to stimulate the growth of plants. Atonic absorbed by the plant will accelerate the flow protoplasmik and activate cell metabolism [7].

\subsection{Number of Roots}

Observational data on the number of roots BST and finger manifold 2 in Annex 9 and 10 which showed that sucrose and atonic significant effect whereas the second interaction effect no significant effect on the amount of roots. Total root age 2 BST on sucrose administration and atonic treatment can be seen in Table 5.

Table 5 shows the highest number of roots on 2 BST obtained at the administration of sucrose $120 \mathrm{~g} / 1$ (S1) and $180 \mathrm{~g} / 1$ is 5.57 significantly different fruits by giving sucrose $60 \mathrm{~g} /$ 1 (S0). The highest number of roots was obtained at giving atonic $1 \mathrm{ml} / 1$ (A1) is 6.89 significantly different fruits to other treatments.

Table 5. Number of root age 2 BST on sucrose administration and atonic treatment.

\begin{tabular}{|c|c|c|c|c|c|}
\hline \multirow{2}{*}{$\begin{array}{l}\text { sucrose } \\
(G / 1)\end{array}$} & \multicolumn{4}{|c|}{ Atonic $(\mathrm{ml} / \mathrm{l})$} & \multirow[b]{2}{*}{ Mean } \\
\hline & $\mathrm{A} 0(0)$ & A1 (1) & A2 (2) & A3 (3) & \\
\hline S0 (60) & $3: 00$ & $5: 33$ & $\begin{array}{l}\text {...fruit } \\
4.67\end{array}$ & $5: 33$ & $4: 58 \mathrm{~b}$ \\
\hline S1 (120) & $4: 33$ & 7.67 & $5: 33$ & 5.67 & $5.75 \mathrm{a}$ \\
\hline S2 (180) & 3.67 & 7.67 & $5: 33$ & $6: 33$ & $5.75 \mathrm{a}$ \\
\hline Mean & $3.67 \mathrm{c}$ & $6.89 \mathrm{a}$ & $5: 11 \mathrm{~b}$ & $5.78 \mathrm{~b}$ & $5: 36$ \\
\hline
\end{tabular}

Table 5 shows the highest number of roots on 2 BST obtained at the administration of sucrose $120 \mathrm{~g} / 1$ (S1) and $180 \mathrm{~g} / 1$ is 5.57 significantly different fruits by giving sucrose $60 \mathrm{~g} /$ 1 (S0). The highest number of roots was obtained at giving atonic $1 \mathrm{ml} / 1$ (A1) is 6.89 significantly different fruits to other treatments.

Statistical analysis of the results showed that administration of sucrose in the culture of potato shoots real effect on shoot length parameters with the best concentration of $180 \mathrm{~g} / 1$ (S2) while the parameter number of shoot and root length best results obtained at a 
concentration of $120 \mathrm{~g} / 1$ (S1). The less the concentration of sucrose used to a certain extent will lead to the increasing number of shoot and root length. Sucrose effects on bud formation in vitro. Giving of sucrose at lower concentrations $(20 \mathrm{~g} / \mathrm{l})$ shows the number of shoots Magnolia $\times$ soulangiana 'Coates' most [6].

Statistical analysis of the results showed that administration of sucrose in the culture of potato shoots real effect on the best length parameter shoots with the data obtained at a concentration of $3 \mathrm{ml} / 1$ (A3) and the number of roots with the best concentration of $1 \mathrm{ml} / 1$ (A1). Atonic higher concentration may increase the length of the shoot but can inhibit the growth of roots, root length where the best results simply by administering $1 \mathrm{ml} / 1$ atonic. In the way it works, atonic quickly absorbed by the plant and stimulates cell protoplasmatik flow and speed of germination and rooting but when the concentration is excessive, it can inhibit the growth [8].

\section{Conclusion}

Giving the best sucrose in the culture of potato shoots obtained at a concentration of 120 $\mathrm{g} / \mathrm{l}$. Giving the best atonic cultured potato shoots obtained at a concentration of $1 \mathrm{ml} / 1$. Best shoot length, diameter obtained in the administration of sucrose $180 \mathrm{~g} / 1$ and atonic $1 \mathrm{ml} / 1$ (S2A1) while the parameter number of shoots the best results obtained in pembrian sucrose $120 \mathrm{~g} / 1$ and atonic $2 \mathrm{ml} / 1$ (S1A2).

\section{References}

[1] Aini, KH. Production of flour kentang. Skripsi. UPI- Jakarta (2012).

[2] Central Bureau of Statistics. Vegetable production in Indonesia from 2011 to 2015. The Central Bureau of Statistics and the Directorate General of Horticulture (2015)

[3] Wanisa. Plant growth regulator substances. Bogor. Inter-University Center. IPB. Bogor (2006).

[4] Mariani, N. Analisa Farming Potato (Solanum tuberosum L.) amongst Using Tissue Culture Seed Certified (G4) with Seed Local in Sungai Puar Batagak Kanagarian Agam.Skripsi district. Andalas University. Padang. Comparison of Revenue and Profits (2011)

[5] Moeini. Analysis of Growing Potato (Solanum tuberosum L.) in Dataran Meium With Some Plant Spacing. Sam Ratulangi University. Manado (2011).

[6] Wojtania GA. Grade Potato Propagule Development of Excellence in Supporting Improved cultivars Pproduksi Chips in scientific Indonesia. Orasi Professor of Horticultural Science, Faculty of Agriculture, IPB. Bogor. 86p (2015)

[7] Culture Technique Jaringan. PAU Wiwit Bogor. 252 p (2003).

[8] Anonymous. Tissue Culture Technique Tumbuhan.Departemen Education and Culture Directorate General of Higher Education University Center of Biotechnology, Bogor Agricultural University. Bogor: 165 p (2006). 